\title{
Tensions Associated With Enacting Care Theory: A Self Study
}

\author{
Katherine Tucker \\ Brian Lewthwaite \\ James Cook University
}

etropic 14.1 (2015): 123-130. http://www.reefandleaf.com.au/etropic.html \& http://www.jcu.edu.au/etropic

\begin{abstract}
This study attempts to locate care and caring in teaching practice. Specifically, the study examines how one pre-service teacher, with a personal imperative to care, mediates the space between performativity and caringUsing self-study methodology, the study attempts to make sense of the "theory/action dialectic" (Osborne, 2003, p. 17) of enacting care theory in a classroom through these tensions. Through the recursive analysis of a self-study research portfolio with a critical friend, the study revealed two key tensions between one's actions and intent and between safety and challenge. The study produced significant implications for my own personal and pedagogical development as a beginning teacher. Furthermore, it has implications for future research into pre-service teacher learning and the way teachers both problematise their practice and consider care in early childhood classrooms.
\end{abstract}

Keywords: Care Theory; Teacher Education; Self-study

\section{Introduction}

\section{An Ethic of Care}

There is no doubt that education is a caring endeavour. The very roots of early childhood education, in particular, are grounded in child-centred principles and caring pedagogies (Feeney, Christiansen, \& Moravcik, 2001). Simply, care is about human beings and the investment of self in relationships. Care is an intellectual and challenging activity and is foundational to ethical pedagogy. In Noddings'(2003) theory, caring is a relation, it requires a person caring (one-caring) and a cared-for.

Interestingly, care is not highly prevalent in early childhood education literature. An English study by Luff (2012) found that, in early childhood education, caring is both evident and considered as pedagogically skilled work, yet this very dimension of early childhood pedagogy undermines the status of the work. The study concluded by calling for fuller exploration into care in relation to the work and experiences of early childhood educators. Whilst there were several studies which have identified the role, importance and paucity of 
care and care discourses (for example, Hackenberg, 2010; Lewthwaite \& McMillan, 2010; Nichol et al., 2010; Waghid \& Smeyers, 2013) there is limited literature specifying the ways teachers themselves recognise and manage the tensions in implementing care in early years or primary school settings.

\section{Performativity and Managerialism}

As a nation, Australia values the role of education in a just and democratic society (Ministerial Council on Education, Employment and Youth Affairs, 2008). But a national schooling agenda aligned to a neo-liberal context means that schooling has become highstakes, performance and productivity driven where pedagogy is inextricably linked to curriculum and evaluation (Lingard, 2010). Ball (2006 as cited in Lingard, 2010) engages the concept of performativity - a culture, a mode of regulation that is based on rewards and sanctions where "performance is a measure" (p. 144) - to explore the consequences of the Australian education agenda.

The result for teachers is a strongly felt need to take responsibility for, and provide evidence of, the quality of their practice. This is particularly so for teachers in early childhood classrooms in primary schools who find themselves in a site of significant and unique set of tensions (Petriwskyj, O'Gorman, \& Turunen, 2013). Foundation year early childhood teachers, in particular, find themselves in a contested space between the scholar-academic and social-efficiency ideologies of the Australian Curriculum and the learner-centred socialreconstructionist ideologies of early years teaching as represented by Early Years Learning Framework (Petriwskyj et al., 2013). These competing ideological perspectives are evident in the enacted curriculum, pedagogies and hidden curriculum of Foundation year classrooms as teachers mediate the tensions (Luke, 2010 as cited in Gibbons, 2007, 2011; Petriwskyj et al., 2013).

\section{Tensions in Teaching and Early Childhood Practice}

Tensions in teaching are not polar concepts, concerns or binaries. They are goals and intentions that exist simultaneously and are captured in the "inner turmoil” (Berry, 2008, p. 32) that teachers' experience. Pre-service teachers experience a unique set of tensions during their practicum settings where expectations of pre-service teacher and schools often collide (Patrick, 2013; Sinclair, Munns, \& Woodward, 2005). Pre-service teachers, and their supervising schools and teachers, have shifting views of the practicum experience viewing it somewhere between an opportunity to innovate and collaborate and an "assimilation into the profession” (Patrick, 2013, p. 207; Sinclair et al., 2005). The literature is concerned about the cycle of hegemony that perpetuates with each generation of teachers co-opting, and thus confirming, the status quo (Brookfield, 1995; Loughran, Brown, \& Doecke, 2010; Patrick, 2013; Sinclair et al., 2005). Stacey, Brownlee, Thorpe \& Reeves (2005) state this is particularly significant for early childhood teachers who have the potential to influence the ongoing relationship children will have with knowledge into adulthood.

The research focus:

The aim of this study is to articulate, document and analyse the tensions associated with enacting care theory whilst preparing to be a teacher in a North Queensland early childhood 
context. Specifically it asked, in what ways are these tensions mediated in the enactment of care pedagogies? And, how does a teacher mediate these tensions?

\section{Methodology}

Self-study was used in this study to highlight the benefits of mediating self in the 'murky' tensions in teaching as a social practice (Pinar, 2004). It employed critical and transformative epistemologies to do this. The site of this research was my pre-service practicum which was one of my final graduating requirements for a Bachelor of Education (Early Childhood Education). This practicum occurred in a preparatory (Foundation Year) class of four and five year old students in a regional primary school in North Queensland. The site was identified as a care-enabling environment.

The research design of this self-study was consistent with that recommended by Samaras (2010). A self-study portfolio was used to catalogue and analyse the data collected in a systematic way using PebblePad+ e-portfolio. This study occurred over a 12 month period and was organised chronologically into three distinct phases: before, during and after enactment of teaching. This three phase approach is recommended by Samaras (2010) for the novice portfolio model.

In before-enactment phase, the research questions were authored, both self and the classroom were observed, a critical friendship with my advisor was established and a critical analysis of the study context occurred. During this phase, the data highlighted a range of possible tensions to serve as a priori themes to explore during the study.

The during-enactment phase occurred during my final block of my final year practicum at the research site over a period of five weeks. Here data collection was inductive and recursive and included a self-study research log and observations. These served to evidence my enactment of care theory and the ways in which I mediated (or not) the tensions that emerged.

The objective of the third and final phase was critical collaborative analysis of the self-study portfolio. This was hermeneutic and where I engaged a critical friend to undertake recursive consideration of the data to uncover 'faulty facts' to identify problematic practice (Berry, 2008; Kosnik, Beck, Freese, \& Samaras, 2006; Loughran, 2004a; Samaras, 2010).

\section{Data Analysis}

The self-study portfolio was subject several rounds of analysis. Firstly broad and thematic, then later, using a logico-inductive process, I analysed the data five times in total. Each time with a different focus, a 'new look', to problematise my teaching. I used Noddings' theory as a critical lens to examine the practices that might manifest care but also "seem to make our teaching lives easier but actually work against our long term interests” (Brookfield, 1995, p. 8).

The revelations after recursions of analysis were distressing and disturbing. It led me to see many parallels between my study and two specific tensions in teaching identified by Berry (2008). 


\section{Results}

\section{The Language of Efficiency and Managerialism}

The analysis revealed a predominance of managerial and performance-based language in the data. These were identified in the literature as rationalist and objective terms- similar to language used in business (Bourke et al., 2013). What was surprising and disturbing, for both me and my critical friend, was the almost absence of a language of care - a troubling trend evident throughout the self-study portfolio. A deeper 'look' unveiled a set of assumptions and practices that would have likely gone unexamined using the initial themes and simple reflective practice. The trend of concerns for efficiency, control and being seen to be competent were just some of the deeper and disturbing themes identified.

\section{Dominant Themes and Tensions}

I was able to identify that there were two broad tensions evident in the data highlighting competing imperatives. The first tension was I was working towards an ideal but jeopardised that idea by the way I tried to reach it. The second was highlighted by desire to 'survive' practicum, to fit in to my pre-service context, and to practice a pedagogy of care and realise my own teaching identity. These had been identified previously by Berry (2008) as the tensions between 'action and intent' and the tension between 'safety and challenge'. Evident in the data was the interplay of these two main tensions - my 'ways' of working towards an ideal were an outward operationalisation of my desire to both survive practicum and enact my teaching philosophies.

\section{Discussion}

Research Question 1: What tensions exist, support and impact pedagogies of care?

This study is a specific example of how an analysis of tensions can problematise the 'conversation' a teacher has with the self and the context so to uncover hegemonic practices. I address these two tensions in turn in relation to the absence of care evidenced in the data.

Tension 1: action and intent. Berry (2008) argues the tension between action and intent is evident when the goals educators set out to meet are compromised by the ways set out to meet them. Further, Berry states that working with this tension acknowledges that a better understanding of the relations between one's intent and one's action can help to reconcile the two, and I argue, so one may take more critical and 'informed actions' (Brookfield, 1995). Understanding my teaching through the lens of this tension has helped me to have greater insight into the ways I was unaware that I was undermining my own goals.

I entered the research context with a premise of care and imperative to operate as one-caring to elicit caring relations in the classroom. What was detriment to my actual caring was a 'plan' to care. Suddenly, rather than an implicit ethic, caring became a 'thing to do', measure and evaluate. An example from the data, an instance where I 'planned' to care, illustrates 
this, I wrote, "I've set an explicit goal (...) I want the children to want to come to school, that I made their day better in some way and that they feel cared for. And that, in turn, they will care for others”. I set specific 'things to do' such as "model engrossment', “confirm and affirm" and "attend" to students according to Noddings theory. By doing this, I contradicted the very theory on which my actions were planned. Noddings (2003) theory states there are "great means of nurturing the ethical ideal" (p. 182) but care cannot be measured or reciprocated. The data showed I shifted care to task-centred ideologies and aligned to 'good' and 'measureable' teaching discourses of efficiency - tied to 'quality' and performance (Pinar, 2004). Thus, it moved myself and the students into "abstraction and objectivity" (Noddings, 2013, p. 182) - resulting in great concern for 'problems' but in loss of care for people.

These actions were not only about 'good teaching' alone it was closely linked to a desire to be recognisably 'good' and competent in my pre-service teacher role, so as to 'survive' my final year practicum.

Tension 2: safety and challenge. To contextualise the significance of this tension, I extend upon the context of the study. The site of this study was my final year practicum classroom. In this setting I was a final year pre-service teacher operating under the supervision of a supervising beginning teacher educator who both mentors my practice and evaluates it against the Australian Professional Standards for Teachers for graduate teachers (Australian Institute for Teaching and School Leadership [AITSL], 2012). Success in this final practicum determined whether or not I graduated from my four year pre-service program the stakes, for me, were high. This is significant in relation to this second tension identified in the data. The data pointed to my desire to be seen to be competent, to 'fit in', and to have a successful practicum. It also pointed to my aversion to taking risks that might have jeopardised my practicum. The dissonance this generated served as an indicator of the tensions between safety and challenge I had experienced. Deeper analysis, as a result of this self-study, uncovered that I was aligning with a discourse unconsciously to standardise certainty, to avoid 'rocking the boat' or being seen to 'over-think' problems. These are problems consistent with those for other pre-service teachers (Patrick, 2013; Sinclair et al., 2005). Furthermore, the vulnerability for pre-service teachers, to do well, but to rely on others for that success, means that one places 'fitting in' at odds with caring relations and the risk of being marginalised by ones actions.

\section{Research Question 2: How does a teacher mediate these tensions?}

To mediate means 'to reconcile... to bring about peace or agreement' therefore, here I discuss three ways in which the study has done this. The first is through critically reflective practice and second through a view of curriculum-as- "problematised" (McLachlan et al., 2010, p. 29) and curriculum-as- "complicated conversation” (Pinar, 2004, p. 208) rather than as instructive.

Whilst the data itself represents an uncritical and simple reflective stance, the contextualised autobiographical methodology using the lens of tensions, mean that I have begun to clear the 'murky ground' in my own teaching. Autobiographical methodologies and, in particular, self-study creates the "necessary uncertainty in the field of education wherein teachers (...) 
[question] what they are doing and how this questioning might enhance professional practice" (Mitchell, Weber, O’Reilly \& Scanlon, 2005, p. 1). Furthermore, Mitchell et al. (2005) states that it offers a powerful and transformative way of "questioning what happens in classrooms from the perspective of teachers” (p. 1). This study revealed 'illusions' of care through a critical, and confronting, walk through my 'conversation' with my own imperative, as enacted curriculum, has provided transformation for genuine care pedagogies in the future.

To take an autobiographical 'look' teachers, particularly pre-service teachers, must arguably problematise what 'is' curriculum. In this study, it was clear that I viewed curriculum as instruction and that my quality as a teacher was solely tied to the scholar-academic 'performance' of my students and that my success would be tied to how this 'looked'. This is problematic, as can be seen in this study. Approaching "curriculum-as-complicatedconversation” (Pinar, 2004, pp. 185-201) ties the autobiographical, social, moral and political to pedagogy (Brookfield, 1995; Pinar, 2004). Whilst difficult, and troubling, it was a worthy exercise as it aided a deeper re-alignment between self and curriculum, between my actions and my intent, and between taking risks and 'surviving' the complex world of teaching.

\section{Conclusion}

In this study, it was clear that I viewed curriculum as instruction and that my quality as a teacher was solely tied to the scholar-academic 'performance' of my students and that my success would be tied to how this 'looked'. This is problematic, as can be seen in this study. Approaching “curriculum-as-complicated-conversation” (Pinar, 2004, pp. 185-201) ties the autobiographical, social, moral and political to pedagogy (Brookfield, 1995; Pinar, 2004). This study aided a deeper re-alignment between self and curriculum, for my future work with very young children entering their relationship with education; I feel this was an invaluable and rewarding outcome.

This study calls pre-service teachers to consider the ways the dominant discourses in the current educational milieu work to disconnect teachers actions from their intent. It provides example of how a teacher seeks instructional solutions to epistemological problems. It provides example of how a teacher's responsibilities privately disguised as autonomy and competency cause one to care instrumentally rather than ethically.

In this study, I have made claims about my enactment of care that were confronting and complex. But I illustrate the complexities of caring relations because as Noddings states, [If] we can understand how complex and intricate, indeed how subjective, caring is, we shall perhaps be better equipped to meet the conflicts and pains it sometimes induces. Then, too, we may come to understand at least in part how it is that, in a country that spends billions on caretaking of various sorts, we hear everywhere the complaint, 'Nobody cares' (p. 12). 


\section{Works Cited}

Australian Institute for Teaching and School Leadership [AITSL]. (2012). Australian Professional Standards for Teachers. Retrieved 18 March, 2013, from http://www.teacherstandards.aitsl.edu.au/

Berry, A. (2008). Tensions in teaching about teaching: understanding practice as a teacher educator (Vol. 5). Netherlands: Springer.

Brookfield, S. (1995). Becoming a critically reflective teacher. San Francisco: Jossey-Bass.

Feeney, S., Christiansen, D., \& Moravcik, E. (2001). Who am I in the lives of children? . New Jersey: Merrill Prentice Hall.

Gibbons, A. N. (2007). The politics of processes and products in education: an early childhood metanarrative crisis? Educational Philosophy and Theory, 39(3), 300-311.

Gibbons, A. N. (2011). The incoherence of curriculum: questions concerning early childhood teacher educators.(Report). Australasian Journal of Early Childhood, 36(1), 9(7).

Hackenberg, A. (2010). Mathematical caring relations: a challenging case. Mathematics Education Research Journal, 22(3), 57-83.

Kosnik, C., Beck, C., Freese, A. R., \& Samaras, A. P. (Eds.). (2006). Making a difference in teacher education through self-study: studies of personal, professional and program renewal. Netherlands Springer.

Lewthwaite, B., \& McMillan, B. (2010). "She can bother me, and that's because she cares": what Inuit students say about teaching and their learning. Canadian Journal of Education, 33(1), 140-175.

Lingard, B. (2010). Policy borrowing, policy learning: testing times in Australian schooling. Critical studies in Eduation, 51(2), 129-147.

Loughran, J., \& Russell, T. (2002). Improving teacher education practice through self-study: Routledge.

Loughran, J. J. (2004a). Learning Through Self-Study: The Influence Of Purpose, Participants And Context. International handbook of self-study of teaching and teacher education practices (pp. 151-192): Springer.

Loughran, J. J. (2004b). Student teacher as researcher: accepting greater responsibility for learning about teaching. Australian journal of education, 48(2), 212-220.

Loughran, J. J., Brown, J., \& Doecke, B. (2010). Continuities and discontinuities: the transition from pre-service to first-year teaching. Teachers and Teaching: theory and practice, $7(1), 7-23$.

Luke, A. (2010). Will the Australian national curriculum up the intellectual ante in classrooms? Curriculum Perspectives, 30(3), 59-64.

Ministerial Council on Education, Employment, Training and Youth Affairs [MYCEETYA]. (2008). Melbourne Declaration on Educational Goals for Young Australians. Carlton, Victoria: Ministerial Council on Education, Employment, Training and Youth Affairs.

Mitchell, C., Weber, S., \& O'Reilly-Scanlon, K. (Eds.). (2005). Just who do we think we are? Methodologies for autobiography and self-study in teaching. Oxon: RouteledgeFalmer.

Noddings, N. (2003). Caring: a feminine approach to ethics and moral education. Los Angeles, California: University of California Press.

Noddings, N. (2013). Caring: a relational approach to ethics and moral education. Berkeley: University of California Press. 
Osborne, B. (2003). Preparing preservice teachers' minds, hears and actions for teaching in remote indigenous contexts. Australian Journal of Indignenous Education, 31(2003), $17-24$

Patrick, R. (2013). 'Don't rock the boat': conflicting mentor and pre-service teacher narratives of professional experience. Australian Educational Researcher, 40(2), 207-226.

Petriwskyj, A., O'Gorman, L. M., \& Turunen, T. (2013). The interface of the national Australian curriculum and the pre-Year 1 class in school: exploring tensions. Australasian Journal of Early Childhood, 13(1), 16-22.

Pinar, W. F. (2004). What is curriculum theory? New Jersey: Lawrence Erlbaum Associates, Inc. .

Samaras, A. P. (2010). Self-study teacher research: improving your practice through collaborative inquiry. Thousand Oaks: SAGE Publications.

Sinclair, C., Munns, G., \& Woodward, H. (2005). Get real: making problematic the pathway into the teaching profession. Asia-Pacific Journal of Teacher Education, 33(2), 209222.

Stacey, P., Brownlee, J., Thorpe, K., \& Reeves, D. (2005). Measuring and manipulating epistemiological beliefs in early childhood education students. International Journal of Pedagogies and Learning, 1(1), 6-17.

Waghid, Y., \& Smeyers, P. (2013). Reconsidering ubuntu: on the educational potential of a particular ethic of care. Educational Philosophy and Theory, 44(2), 6-20. 